DOI https://doi.org/10.30525/978-9934-588-37-2.1.19

\title{
ПРОФЕСІЙНИЙ РОЗВИТОК ВЧИТЕЛІВ МИСТЕЦЬКИХ ДИСЦИПЛІН У ПІСЛЯДИПЛОМНІЙ ОСВІТІ
}

\author{
Кондратова Л. Г., Ружицький В. А.
}

\section{ВСТУП}

У період реформування освіти важливого значення набувають проблеми підготовки педагогічних працівників до впровадження інновацій, що відбувається в системі післядипломної освіти.

Нові нормативні документи в галузі освіти, а саме Закони України «Про освіту», «Про повну загальну середню освіту», нові державні освітні стандарти, Концепція «Нова українська школа» та ін. вимагають від системи післядипломної освіти швидкого реагування на освітні реформи та розроблення широкого спектру освітніх послуг, спрямованих на підвищення кваліфікації педагогів закладів загальної середньої освіти та професійний розвиток вчителів за умов післядипломної освіти.

Нова типова програма підвищення кваліфікації педагогічних працівників ${ }^{1}$, розроблена відповідно до вимог Концепції нової української школи, визначає шляхи розвитку професійних компетентностей педагогічних працівників. Типовою програмою передбачено можливість подальшого розширення та поглиблення професійних знань, умінь, навичок педагогічних кадрів у системі неформальної та інформальної освіти, оновлення та поповнення професійних знань у процесі їх практичного застосування.

Основні тенденції реформування освіти передбачають також більші можливості для професійного зростання вчителів, котрі викладають різні шкільні предмети. На законодавчому рівні визнано право сучасного вчителя на самостійний вибір місця підвищення кваліфікації, тому педагог має реальні можливості для педагогічної свободи та свободи у виборі форм навчання в межах неформальної та інформальної освіти. Освітні установи, які займаються підвищенням кваліфікації педагогічних працівників, повинні враховувати потреби й інтереси вчителів щодо набуття практичного досвіду, організацію освітнього процесу в закладах освіти всіх рівнів.

Окрему ланку педагогічних працівників закладів загальної середньої освіти становлять фахівці освітньої галузі «Мистецтво», котрі викладають дисципліни мистецького циклу в початковій,

\footnotetext{
${ }^{1}$ URL: http://search.ligazakon.ua/1_doc2.nsf/link1/TF030830.html.
} 
основній і старшій школі. Об'єктивні потреби в підвищенні якості підготовки вчителів мистецьких дисциплін до організації навчання школярів вимагають нових підходів до професійного розвитку педагогів за умов післядипломної освіти.

Виникає необхідність розроблення нових технологій саморозвитку та самовдосконалення вчителів мистецьких дисциплін з урахуванням їх особистісно-професійних запитів і потреб та професійного досвіду організації мистецької освіти в закладах загальної середньої освіти.

Водночас активний розвиток цифрових технологій i орієнтація на сучасні тенденції розвитку цифровізації освіти, вчителі мистецької освітньої галузі повинні оволодіти новими формами й методами викладання цих предметів із залученням цифрових пристроїв, володіти практичними навичками щодо підготовки новітнього освітнього контенту 3 використанням хмарних, мобільних, інформаційно-комунікативних технологій, підготовки нових засобів візуалізації освітнього процесу.

На сферу післядипломної освіти покладається місія активної підготовки педагогів мистецьких дисциплін до реалізації нового змісту мистецької освіти, яка базується на концептуальних засадах Нової української школи, та впровадження нових методик i технологій XXI ст., пов'язаних із єдністю педагогічних і цифрових технологій у навчанні школярів мистецтву.

Актуальність обраної проблеми доводиться насамперед увагою вчителів мистецької освітньої галузі до оновленого змісту мистецької освіти та їх потребою у постійному професійному розвитку, що здійснюється в умовах формальної, неформальної та інформальної освіти.

Актуальність проблеми також зумовлена активною увагою сучасних дослідників до питань професійного розвитку педагогів в умовах післядипломної освіти. Розгляд актуальних проблем післядипломної підготовки педагогів роботи за умов освітніх реформ, а також розгляд вітчизняного досвіду організації професійного розвитку вчителів мистецьких дисциплін у системі післядипломної освіти на основі опанування цифрових технологій у мистецькій освіті дозволить будувати індивідуальну освітню траєкторію вчителів мистецьких дисциплін і сприяти їх професійному розвитку.

\section{1. Актуальні проблеми професійного розвитку вчителів} мистецьких дисциплін у системі післядипломної освіти

Питання професійного розвитку педагогічних працівників сьогодні дуже актуальні. Проблема професійного розвитку вчителя посідає одне з головних місць. Питання професійного розвитку педагогічних кадрів розглядали як вітчизняні, так i зарубіжні науковці: Н. Гузій, Г. Данилова, Г. Маралов, Л. Мітіна, В. Сластьонін, Ю. Сліпіч та ін. Питання професійного розвитку вчителів у системі післядипломної 
освіти досліджували В. Андрющенко, І. Зязюн, В. Олійник, Т. Сорочан та ін ${ }^{2}$. Питання змісту професійного розвитку педагога висвітлювали Н. Дене Фічтмен, С. Зепеде, М. Ріс, А. Росс; проблеми розбудови систем i моделей професійного розвитку педагогів - Б. Джойс, Л. Інгварсон, С. Кееген, М. Кочрен-Сміт, С. Літл, використання методів і формів професійного розвитку педагогів - П. Гріммет, К. Дуінлен, Дж. Троя, кар'єрний цикл професійного розвитку вчителів - Е. Еріксон, Дж. Крістенсен, 3. Мевареч, Р. Фесслер, М. Хуберман ${ }^{3}$.

На думку українських вчених І. Зязюна, Н. Клокар, В. Олійника, Л. Покроєвої, Н. Протасової, Л. Пуховської, М. Романенко, О. Савченко, С. Сисоєвої, в системі післядипломної педагогічної освіти наукові знання стають фактором розвитку педагогічної практики. На їх основі забезпечується цілісність, неперервність, випереджувальна спрямованість розвитку професіоналізму педагогічних працівників ${ }^{4}$. Система професійного розвитку охоплює ширшу перспективу, до складу якої входять функціональні взаємозв'язки між: цілями та завданнями професійного розвитку; контекстом, у якому відбуватиметься професійний розвиток; особистісними та професійними характеристиками учасників системи; моделями, методикою та способом дії, які застосовуватимуться; коштами й результатами професійного розвитку; визначенням повноважень; процесом оцінювання ефективності професійного розвитку; визначенням інфраструктури підтримки професійного розвитку тощо ${ }^{5}$.

Результатом розвитку професіоналізму керівників і педагогічних працівників загальноосвітніх навчальних закладів має бути позитивна динаміка показників за рівнями сформованості професійних компетентностей ${ }^{6}$. Так, на думку Т. Сорочан, важливу сходинку до рівня професіоналізації, тобто активного формування необхідної

${ }^{2}$ URL: http://otr.iod.gov.ua/images/pdf/2017/10/04.pdf.

3 Мукан Н.В., Грогодза І.Ю. Професійний розвиток педагогів: теоретичні та методологічні аспекти. Педагогічні науки: теорія, історія, інноваційні технологіï. 2013. № 5 (31). С. 18-21.

${ }^{4}$ Сорочан Т.М., Данильєв А.О., Дьяченко Б.А., Рудіна О.М. Професійний розвиток керівників i педагогічних працівників загальноосвітніх навчальних закладів у післядипломній педагогічній освіті регіонального рівня (за матеріалами Луганського обласного інституту післядипломної педагогічної освіти). Луганськ : СПД Рєзніков В.С., 2013. 524 с.

5 Ingvarson L. Professional development as the pursuit of professional standards: the standard based professional development system. Teaching and Teacher Education. 1998. № 14 (1). Р. 127-140.

6 Сорочан Т.М., Данильєв А.О., Дьяченко Б.А., Рудіна О.М. Професійний розвиток керівників i педагогічних працівників загальноосвітніх навчальних закладів у післядипломній педагогічній освіті регіонального рівня (за матеріалами Луганського обласного інституту післядипломної педагогічної освіти). Луганськ : СПД Рєзніков В.С., 2013. 524 с. 
компетентності педагог долає, якщо починає відчувати потребу в цьому. Тоді ж він робить перші спроби, виконує окремі елементи практичних дій застосування нової компетентності у професійній діяльності.

Водночас кожен педагог може здатен до активного впровадження інновацій у свою педагогічну діяльність. Досягнення інноваційного рівня професійної педагогічної діяльності можливе за наявності у педагога не тільки потягу до впровадження інновацій, новизни до використання вже відомих прийомів, методів, методик, технологій, а й до створення принципово нового інтелектуального продукту, який може суттєво вплинути на результати освіти і має соціальну значущість ${ }^{7}$.

Окрему проблему піднімає Т. Сорочан та інші науковці щодо вимог до підготовки проєктів професійного розвитку педагогів, котрі розуміються як спеціально сконструйовані розвиваючі професійні середовища, спрямовані на створення системи безперервної освіти в міжкурсовий період. У цих проєктах реалізується трирівнева структура системи безперервної освіти в міжкурсовий період: інститут готує та сертифікує тренерів, консультантів, експертів, тьюторів, які потім взаємодіють у методичних кабінетах (центрах) i методичних об'єднаннях безпосередньо 3 педагогами у процесі формування необхідних компетентностей ${ }^{8}$.

На основі різних поглядів дослідників ми доходимо визначення поняття, що професійний розвиток є комплексом видів діяльності, яка здійснюється на систематичній основі з метою підготовки вчителів до їхньої професійної діяльності й охоплює початкову підготовку, програми введення у професію, післядипломну підготовку, неперервний професійний розвиток в умовах школи 9 . Всі етапи професійного розвитку розвивають особистісні вміння й навички, знання, набувають певного рівня педагогічна майстерність вчителя та всі їі складники.

У свою чергу, професійний розвиток учителів загальноосвітніх шкіл розглядається як неперервний процес, що охоплює три складники (початкову підготовку, введення у професію та постійне вдосконалення

${ }^{7}$ Сорочан Т.М., Данильєв А.О., Дьяченко Б.А., Рудіна О.М. Професійний розвиток керівників і педагогічних працівників загальноосвітніх навчальних закладів у післядипломній педагогічній освіті регіонального рівня (за матеріалами Луганського обласного інституту післядипломної педагогічної освіти). Луганськ : СПД Рєзніков В.С., 2013. 524 с.

${ }^{8}$ Там само.

9 Scheerens J. Teachers' professional development. Europe in international comparison. An analysis of teachers' professional development based on the OECD's Teaching and Learning International Survey (TALIS). Luxembourg : Office for Official Publications of the European Union, 2010. 204 p. 
особистісних, соціальних і професійних компетентностей педагога) й відповідає кар'єрному розвитку вчителів ${ }^{10}$.

Професійний розвиток вчителів у системі післядипломної освіти $\epsilon$ специфічним, закономірності якого визначаються андрагогікою теорією навчання дорослих.

Розглядаючи проблеми професійного розвитку педагога в системі післядипломної освіти, варто зазначити, що складовими частинами професійного розвитку вчителя є когнітивність: професійне навчання, підвищення кваліфікації; мотивованість: кар'єрне зростання, самопрогнозування, самореалізація; самовизначеність: соціальногромадська діяльність, акме.

Професійний розвиток як процес набуття вчителем нових компетенцій, знань, умінь і навиків дозволяє надалі використовувати отримані знання у своїй професійній діяльності.

Професійний розвиток вчителя $\epsilon$ безперервним комплексним процесом, який включає певні етапи педагогічної діяльності: професійне навчання, що розпочинається в період навчання в закладі освіти; розвиток кар'єри, в який набувають розвитку всі складники педагогічної майстерності, вчитель отримує професійні навички щодо організації освітньої діяльності в закладах загальної середньої освіти й етап підвищення кваліфікації, що відбувається в закладах післядипломної освіти. Окремо розвивається професійність вчителя в період підвищення кваліфікації, це дозволяе вирішувати основні завдання як в інтересах закладу освіти - підвищення ефективності та якості праці, так і в інтересах людини - підвищується рівень життя, створюються нові можливості для реалізації своїх творчих i педагогічних здібностей.

Зважаючи на специфіку педагогічної діяльності вчителів мистецьких дисциплін, серед особливостей професійного розвитку педагогів мистецької галузі слід виділити самобутню специфіку процесу навчання школярів мистецтву. Освітній процес навчання мистецтву в умовах закладів загальної середньої освіти орієнтується на досягнення певної мети, яка спрямовується на формування і розвиток в учнів комплексу ключових, міжпредметних i предметних компетентностей у процесі опанування художніх цінностей та способів художньої діяльності шляхом здобуття власного естетичного мистецького досвіду. Саме тому сучасний вчитель мистецьких

10 Scheerens J. Teachers' professional development. Europe in international comparison. An analysis of teachers' professional development based on the OECD's Teaching and Learning International Survey (TALIS). Luxembourg : Office for Official Publications of the European Union, 2010. 204 p. 
дисциплін повинен мати належний рівень професійної компетентності щодо навчання мистецтву учнів початкової, основної та старшої школи.

Мистецькі дисципліни охоплюють широке поле педагогічної діяльності від викладання музичного мистецтва, образотворчого мистецтва та інтегрованого курсу «Мистецтво» й організації позаурочної мистецької діяльності в гуртках, художніх колективах, мистецької виховної роботи, індивідуальної роботи з обдарованими в мистецтві учнями.

Серед переліку професійний компетентностей вчителів мистецьких дисциплін особливої ваги набувають компетентності педагогів у сфері організації художньо-творчої діяльності школярів, педагогічних умінь щодо сприймання та інтерпретації творів мистецтва, а також умінь здійснювати комунікацію засобами мистецтва.

Вчитель музичного мистецтва повинен постійно розвивати професійні навички щодо виконавської техніки гри на музичному інструменті, поглиблювати професіоналізм у процесі організації вокально-хорової діяльності з учнями різного віку, мати досвід i поглиблювати навички організації прослуховування й аналізу музичних творів, із використанням сучасних засобів звуковідтворення, вміння підключення акустичних систем i постійно працювати над удосконаленням навичок гри на електронних сучасний музичних інструментах, володіти певним рівнем цифрової компетентності тощо.

Вчитель образотворчого мистецтва постійно розвиває рівень професійної компетентності з організації практичної роботи з учнями зі створення композицій із живопису, графіки, практичні навички 3 ліплення, розпису, організації роботи зі створення аплікацій, декорування, створення декоративних виробів, декоративних композицій і пізнання основ архітектури і дизайну тощо. Для сучасного вчителя образотворчого мистецтва важливий саморозвиток у сфері використання сучасних електронних засобів навчання, опанування основ комп'ютерної графіки та графічного дизайну тощо.

Останнім часом набувають особливої актуальності питання професійного розвитку вчителів мистецьких дисциплін щодо організації інтегрованого навчання у викладанні інтегрованого курсу «Мистецтво».

Так, особливу увагу у процесі професійного розвитку вчителю мистецтва слід приділити розвитку професійної компетентності щодо інтегрованого викладання мистецтва. Відомо, що концептуальні засади інтегративного навчання мистецтва базуються на єдності всіх складників: цілей, організації навчання, яке базується на єдності змістових ліній художньо-творчої діяльності, сприймання й інтерпретації мистецтва, комунікації засобами мистецтва до отримання 
очікуваних результатів. Інтегрований підхід у викладанні мистецтва за своєю суттю є засобом, який через підбір навчального матеріалу створює умови для широкого охоплення змісту порівняно із традиційною школою і передбачає скорочення терміну навчання майже вдвічі. Використання інтегрованого підходу в освіті в освітньому процесі відкриває цілий ряд можливостей для різнобічного, нетрадиційного, практичного засвоєння набутих мистецьких знань школярів ${ }^{11}$. Особливу увагу вчитель має приділити розвитку професійних якостей щодо інтегрованого викладання мистецтва, а саме оволодіння практичними навичками поєднання в одному уроці різних видів мистецтв, вміння добирати доцільні форми, методи, технології в інтегрованому навчанні. Вчителю необхідно мати належний рівень практичних вмінь щодо побудови освітнього процесу на засадах компетентнісного підходу, що передбачає набуття цілісного досвіду вирішення життєвих проблем, виконання ключових функцій, соціальних ролей, вияв компетенцій тощо.

Професійний розвиток вчителів мистецьких дисциплін відбувається одночасно в кожному із видів освіти: у формальній, неформальній та інформальній освіті вчителя мистецьких дисциплін, яке базується на грунтовному науково-методичному супроводі в межах післядипломної педагогічної освіти. Формальна освіта, що проходить у процесі підвищення кваліфікації педагогів будується на модульному навчанні та має велике практичне значення у набутті вчителями мистецької галузі нових форм і технологій організації навчання мистецтву. У ст. 8 Закону України «Про освіту» регламентуються всі види освіти педагогів, а неформальна освіта характеризується як освіта, що здобувається зазвичай за освітніми програмами та не передбачає присудження визнаних державою освітніх кваліфікацій за рівнями освіти, але може завершуватися присвоєнням професійних та / або присудженням часткових освітніх кваліфікацій ${ }^{12}$. Неформальна освіта має такі ознаки: організованість, систематичність, доповнюваність знань, здобутих на попередніх етапах навчання, що грунтується на рівні конкретних суб'єкт-суб'єктних відносин і фактично залишається поза межами державного регулювання, має широкий спектр вибору форм для здійснення професійного розвитку вчителів мистецьких дисциплін. На думку Л. Лук'янової, саме неформальна освіта є ланкою єдиного ланцюга неперервної освіти та професійного розвитку людини впродовж життя і характеризується як складна соціально-педагогічна

${ }^{11}$ URL: http://www.model.poltava.ua/index.php?option=com_content\&view=article\& id=377:metod-integra.

12 Закон України «Про освіту». URL: http://osvita.ua/legislation/law/2231/3,c.1. 
поліфункціональна система, спрямована на задоволення фундаментальних потреб людини в освіті, культурі, саморозвитку, самореалізації власних сутнісних сил ${ }^{13}$.

До усталених форм навчання вчителів мистецької галузі в неформальній освіті слід віднести: залучення вчителів до участі в науковопрактичних, науково-методичних заходах, участь вчителів у діяльності творчих об'єднань, педагогічних фестивалів і конкурсів тощо ${ }^{14}$.

Інформальна освіта вчителів мистецької галузі здійснюється на основі самонавчання й активного професійного саморозвитку на основі мережевого навчання та підвищення професійного рівня у процесі роботи педагогів над методичною темою самоосвіти й узагальненням педагогічного досвіду.

Отже, професійний розвиток вчителів мистецької галузі у процесі підвищення кваліфікації педагогів мистецьких дисциплін здійснюється в період курсового та міжкурсового навчання у формальній освіті, а також під час участі педагогів у конференціях, семінарах, науковометодичної та науково-дослідної роботи в неформальній освіти та завдяки самонавчанню та мережевому спілкуванню та взаємодії, за наявності потреби у розбудові індивідуальної освітньої траєкторії в інформальній освіті.

\section{2. Цифрові технологій у професійному розвитку вчителів} мистецьких дисциплін за умов післядипломної освіти

XXI століття - це час великих перетворень, становлення інформаційного суспільства, пришвидшеної інноватизації та мережевих зв'язків. У період активного розвитку цифровізації суспільства постає потреба впровадження цифрових технологій у всі сфери освіти, в т. ч. й післядипломної. Цифрова освіта - це освіта, яка головним чином функціонує за рахунок цифрових технологій, тобто електронних транзакцій, що реалізуються шляхом використання Інтернету. Цифровізація навчання дозволяе збільшити віртуальну мобільність педагогів, котрі постійно підвищують рівень свого професійного розвитку. Цифровізація освітніх послуг в Україні дозволяє конкурувати в межах єдиного європейського освітнього простору.

Використання цифрових технологій в освітньому процесі набуває особливої актуальності. Саме розвиток цифрової компетентності сучасного вчителя стає важливою сходинкою до загального професійного

13 Лукьянова Л. Неформальна освіта дорослих як невід'ємна складова освіти впродовж життя. URL: http://www.uaod.org.ua/data/PRO_OSVITU_DOROSLYH/ unformal_OD.PDF

${ }^{14}$ Кондратова Л.Г. Професійний саморозвиток вчителів музичного мистецтва в інформальній освіті. Virtus. Scintific Journal. Вип. 35. 2019. С. 118-122. 
розвитку педагога. На систему післядипломної освіти покладена місія забезпечення нової якості педагогічних працівників, здатних ефективно здійснювати професійну діяльність у ситуації нестабільності, невизначеності й постійних змін шляхом створення умов їхнього неперервного особистісного і професійного розвитку впродовж усього життя та вдосконалення (інноваційних перетворень) всіх елементів системи післядипломної педагогічної освіти, а також освітньої галузі загалом відповідно до змінних умов. Водночас для виконання цієї місії система післядипломної педагогічної освіти має не просто відповідати на швидкоплинні соціально-політичні й економічні суспільні зміни, а й прогнозувати та випереджати їх ${ }^{15}$. Одним із завдань післядипломної освіти в період розвитку цифрових технологій $є$ підготовка сучасного вчителя до оволодіння знаннями та практичним досвідом щодо упровадження цифрових технологій в освітній процес закладів загальної середньої освіти.

На необхідності професійного розвитку педагогів і впровадження інновацій наголошують сучасні концепції освіти, серед яких Концепція нової української школи. Вона окреслює орієнтири для професійного розвитку вчителів, а саме: орієнтування на активність того, хто навчається; на досвід і знання; на доброзичливе оцінювання зі зворотнім зв'язком; на формування професійної спільноти 3 горизонтальними зв'язками. Важлива роль відведена цифровій компетентної вчителя й учня ${ }^{16}$. Як зазначає Концепція, наскрізне застосування цифрових технологій в освітньому процесі закладів освіти має стати інструментом забезпечення успіху нової української школи. Важливість інформаційно-цифрової компетентності окреслено в Концепції нової української школи. Вона «передбачає впевнене, водночас критичне застосування інформаційно-комунікаційних технологій (ІКТ) для створення, пошуку, обробки, обміну інформацією на роботі, в публічному просторі та приватному спілкуванні. Сучасні вчителі мають поступово оволодівати новим професійними якостями, такими як інформаційна і медіаграмотність, основи програмування, алгоритмічне мислення, робота з базами даних, навички безпеки в інтернеті та кібербезпеки, розуміння етики роботи 3 інформацією (авторського права, інтелектуальної власності тощо) ${ }^{17}$. На потребі у

${ }^{15}$ URL: https://lib.iitta.gov.ua/5798/1/tmpA469.pdf.

16 Нова українська школа. Концептуальні засади реформування середньої освіти / Міністерство освіти і науки України. 2016. С. 11-12. URL: https://www.kmu.gov.ua/storage/app/media/reforms/ukrainska-shkola-compressed.pdf.

${ }_{17}$ Ghrynevych, L., Eljkin, O., Kalashnikova, S., Kobernyk, I., Kovtunecj, V., Makarenko, O., Shyjan, R. New Ukrainian School: Conceptual Principles for Reforming the Secondary School. 2016. URL: https://www.kmu.gov.ua/storage/app/media/reforms/ ukrainska-shkola-compressed.pdf. 
професійному розвитку педагогічних кадрів наголошено також у ст. 59 Закону про освіту, яка визначає необхідність постійної самоосвіти педагогів, участі у програмах підвищення кваліфікації та будь-яких інших видах і формах професійного зростання. Закон передбачає, що підвищення кваліфікації може здійснюватися за різними видами (навчання за освітньою програмою, стажування, участь у сертифікаційних програмах, тренінгах, семінарах, семінарахпрактикумах, семінарах-нарадах, семінарах-тренінгах, вебінарах, майстер-класах тощо) та у різних формах (інституційній, дуальній, на робочому місці (на виробництві) тощо). Вид, форму та суб'єкта підвищення кваліфікації обирає педагогічний працівник ${ }^{18}$. Водночас низка нормативних документів наголошує на необхідності постійного розвитку цифрової компетентності сучасних вчителів, так, відповідно до стандартів цифрової компетентності вчителя, визначених ЮНЕСКО, визначаються три рівні: набуття знань, поглиблення знань, створення знань. Кожен із цих рівнів розглядається відповідно до 5 аспектів: розуміння ІКТ в освітній політиці, навчальний план i оцінка, педагогіка, застосування цифрових навичок, організація й управління та професійне навчання вчителів ${ }^{19}$. 3 метою професійного розвитку вчителів мистецьких дисциплін в умовах післядипломної освіти запроваджується багато різних видів навчання педагогів. До ефективних форм навчання в межах післядипломної освіти відносять такі форми навчання, як: педагогічні тренінги, майстер-класи, практичні семінари, цифрові майстерні тощо. На таких короткострокових заходах вчителів мистецьких дисциплін навчають педагоги-тренери, досвідчені педагоги-андрагоги. Аналіз вітчизняного досвіду тренінгового навчання цифрових технологій на базі закладів післядипломної освіти для вчителів мистецьких дисциплін доводить, що такі форми навчання охоплюють звужене коло проблем щодо використання цифрових технологій в мистецькій освіті. Наприклад, педагогічні тренінги та семінари всеукраїнського й обласного рівня щодо оволодіння технологіями Веб-2.0, використання інструментів Google в освітньому процесі, впровадження цифрових та проєктних технологій тощо. Результатом такого навчання $\epsilon$ набуття практичного досвіду щодо використання цифрових технологій у викладанні мистецьких дисциплін та отримання сертифікату, який засвідчує рівень розвитку цифрової компетентності педагога.

\footnotetext{
${ }^{18}$ Law of Ukraine on the Education of the Verkhovna Rada № 38-39, art. 380. 2017. URL: https://zakon.rada.gov.ua/laws/show/2145-19.

${ }^{19}$ Unesco. Unesco Ict Competency Framework For Teachers. Unesco, Paris. 2018. URL: http://unesdoc.unesco.org/images/0026/002657/265721e.pdf.
} 
Останнім часом у практиці вітчизняних закладів післядипломної освіти поширеним явищем стало проведення тематичних та авторських курсів для вчителів мистецької галузі. Для вчителів музичного мистецтва доцільним $є$ проведення тематичних курсів та авторських тренінг-курсів щодо оволодіння грою на електронних музичних інструментах, набуття практичних навичок щодо роботи зі звуковими редакторами й цифровими програмами для аранжування музичних творів, запису нотного тексту та роботи над створенням навчального відео, сучасними сервісами щодо підготовки аудіо-візуального супроводу освітнього процесу та багато інших.

Для вчителів образотворчого мистецтва доцільним стане проведення тематичних та авторських курсів щодо оволодіння основами комп'ютерної графіки, веб-дизайну, вміння працювати 3 програмами для створення колажів, плакатів, інфографіки тощо.

Для педагогів, котрі викладають інтегрований курс «Мистецтво», важливою $\epsilon$ підготовка відео-майстер-класів, які демонструють технологію й етапи роботи над створенням живописних композицій, ліплення, аплікації, іграшок, розписів тощо. Доцільно навчати вчителів інтегрованого курсу на тематичних курсах, що дозволять набути практичних навичок щодо використання цифрових продуктів та електронних засобів в освітньому процесі, а також навчатимуть педагогів самостійно створювати майстер-класи на основі сучасних веб-сервісів, мобільних додатків і цифрових програм.

Цікавий досвід підготовки вчителів мистецької галузі до викладання інтегрованого курсу «Мистецтво» на основі дистанційного навчання має видавництво Навчальна книга-Богдан (Тернопіль). Так, було організовано та проведено два авторські всеукраїнські дистанційні курси для вчителів мистецької освітньої галузі під назвою «Цифрові технології в мистецькій освіті» (автора Л.Г. Кондратової) на 150 та 30 годин навчання. Протягом двох років навчання за дистанційним курсом пройшло понад 800 вчителів мистецьких дисциплін 3 усіх областей України. Навчання за дистанційним курсом було організовано в освітньому середовищі Google Клас. На основі рефлексивної анкети й аналізу створених електронних i цифрових продуктів всі слухачі дистанційного курсу підвищили цифрову компетентність, набули практичних навичок щодо підготовки візуального супроводу освітнього процесу, роботи 3 електронними інтерактивними матеріалами, що значно сприяло професійному розвитку педагогів.

Останнім часом як окремий вид професійного досвіду вчителів мистецьких дисциплін розвиваються літні школи професійної майстерності, які своєю метою ставлять обмін досвідом і поширення інновацій серед педагогів освітньої галузі «Мистецтво». 
В умовах післядипломної освіти з'являються різноманітні новітні види курсової перепідготовки, такі як очні, очно-дистанційні, дистанційні, дуальні тощо. Дистанційне навчання широко поширюється у багатьох країнах світу і щороку його популярність стрімко зростає. Відомо, що дистанційна форма навчання становить альтернативу традиційному очному навчанню.

Дистанційне навчання, яке більшістю науковців транслюється як індивідуальний процес передачі та засвоєння знань, умінь, навичок $\mathrm{i}$ способів пізнавальної діяльності людини, дозволяє за опосередкованої взаємодії віддалених один від одного учасників навчання, реалізувати всі освітні завдання на основі спеціалізованих інформаційних освітніх середовищ, дистанційних платформ.

Дистанційна форма навчання розглядається рівноцінно 3 очною, заочною, що реалізується переважно за технологіями дистанційного навчання, які складаються 3 органічного поєднання педагогічних та інформаційних технологій та організовується відповідно до робочих навчальних планів і затверджуються наказом керівника закладу освіти.

За дистанційною формою навчання основні заняття, що проводяться дистанційно, забезпечується на основі передачі відео, аудіо, графічної та текстової інформації у синхронному й асинхронному режимах.

Як зазначено у концепції дистанційної освіти, для забезпечення дистанційного навчання слухачів курсів підвищення кваліфікації навчальний заклад може створювати власні веб-ресурси або використовувати інші веб-ресурси, що підлягають перевірці у цьому навчальному закладі. Перелік веб-ресурсів навчальних дисциплін (програм), необхідних для забезпечення дистанційного навчання, визначається закладом освіти залежно від профілю навчальної дисципліни та розробляє відповідні методичні рекомендації ${ }^{20}$.

Актуальним питанням післядипломної освіти стає також організація дистанційного навчання вчителів освітньої галузі в період курсової перепідготовки, а також як самостійний вид навчання, організований на платформах дистанційного навчання та в освітньому середовищі Google та ін.

Google Клас - безкоштовний сервіс для закладів освіти, некомерційних організацій і користувачів особистих облікових записів Google. У ньому можна створювати навчальні курси, призначати i перевіряти завдання. Автоматизація рутинної частини освітнього процесу економить викладачам час, спрощує організацію освітнього процесу і забезпечує ефективну комунікацію зі слухачами.

${ }^{20}$ URL: https://mon.gov.ua/ua/osvita/visha-osvita/distancijna-osvita. 
Організація дистанційного навчання вчителів мистецьких дисциплін в освітньому середовищі Google Клас і досвід організації авторських курсів засобами інструментів Google довів, що навчатися в дистанційному режимі одночасно може велика кількість педагогів, які розподіляються за навчальними групами й отримують практичні завдання, пов'язані із засвоєнням практичних навичок щодо використання цифрових інструментів у педагогічній мистецькій діяльності.

Останнім часом розвиваються нові форми неформальної освіти й удосконалюються види формальної освіти педагогів. Популярними стають різноманітні форми самоосвітньої інформальної освіти педагогічних спільнот на основі мережевого навчання на вебінарах, відкритих дистанційних курсах, педагогічних марафонах, відкритих онлайн-студіях тощо.

Так, вчителі мистецької галузі мають змогу самостійно підвищувати професійний рівень на основі мережевих форм навчання й отримувати сертифікат про набуття практичного досвіду щодо використання цифрових i педагогічних технологій у практичній професійній діяльності.

Для вчителів музичного мистецтва поширеним явищем стала участь у мистецьких конкурсах, коли педагог надсилає відеовиступ вокалісту або вокальній групі для участі в Інтернет-конкурсі.

Для вчителів образотворчого мистецтва організовуються віртуальні виставки творів образотворчого мистецтва із можливістю перегляду та відвідування онлайн. Існує досвід надання онлайн-консультацій для вчителів мистецької галузі та використання віртуальних майстер-класів і різноманітних видів самонавчання.

Для особистісного професійного розвитку вчителів мистецьких дисциплін важливого значення в сьогоденні набувають форми онлайнекскурсій по віртуальним музеям світу через додаток Google Arts \& Culture. Додаток має доступ більш до 75 найвидатніших музеїв мистецтва світу та здійснення мистецьких подорожей онлайн.

Мережеві мистецькі педагогічні спільноти надають можливості обміну педагогічним досвідом, поширення педагогічних інновацій, спілкування та взаємодії в межах України та світу, що значно впливає на професійний розвиток вчителів мистецької галузі.

\section{ВИСНОВКИ}

Проведене дослідження проблеми професійного розвитку вчителів мистецьких дисциплін в умовах післядипломної педагогічної освіти довело, що проблема професійного розвитку як комплекс видів діяльності викликає зацікавленість серед науковців і педагогів- 
практиків. На всіх етапах свого професійного розвитку вчителі мистецької освітньої галузі розвивають особистісні вміння й навички, знання, набувають певного рівня розвитку педагогічної майстерності.

Професійний розвиток вчителів мистецьких дисциплін здійснюється в умовах формальної, неформальної та інформальної освіти. Особливого значення професійний розвиток набуває під час підвищення кваліфікації на основі тематичного навчання. У період реформування мистецької освіти значна увага вчителів мистецької освітньої галузі прикута до опанування технологій упровадження оновленого змісту мистецької освіти в практику професійної діяльності в умовах закладів загальної середньої освіти. Професійний розвиток вчителів мистецької галузі продовжується у процесі міжкурсового навчання у формальній освіті, а також під час участі педагогів у конференціях, семінарах, науково-методичній i науково-дослідній роботі в неформальній освіті та завдяки самонавчанню та мережевому спілкуванню та взаємодії, за наявності потреби у розбудові індивідуальної освітньої траєкторії в інформальній освіті.

Активна увага вчителів мистецьких дисциплін прикута до проблеми упровадження цифрових технологій в освітній процес закладів загальної середньої освіти. Розповсюдженими формами навчання педагогів стають тематичні й авторські курси, участь педагогів у майстер-класах, тренінг-курсах, цифрових майстернях, спрямованих на розвиток цифрової компетентності вчителів і набуття ними знань i практичного досвіду впровадження цифрових технологій в освітній процес закладів загальної середньої освіти. Поширюється дистанційна форма навчання в освітньому середовищі Google Клас на основі програми авторських курсів і різні форми мережевого навчання, взаємообміну та спілкування, що сприяє професійному розвитку вчителів мистецьких дисциплін.

\section{АНОТАЦІЯ}

Розділ присвячений актуальній проблемі професійного розвитку вчителів мистецьких дисциплін у післядипломній освіті. Розглянуто особливості професійного розвитку вчителів мистецьких дисциплін в усіх видах навчання: у формальній, неформальній та інформальній освіті. Виділено освітні потреби вчителів мистецької галузі щодо професійного розвитку. Описано досвід навчання вчителів на основі тематичних та авторських курсів у формальній освіті. Зазначено освітні потреби вчителя музичного мистецтва, образотворчого мистецтва та інтегрованого курсу «Мистецтво» в умовах післядипломної освіти. Описано актуальні потреби вчителів мистецьких дисциплін щодо використання цифрових технологій в освітній діяльності в умовах 
закладів загальної середньої освіти. Визначено тематику й освітні потреби вчителів щодо використання цифрових технологій у процесі викладання музичного, образотворчого мистецтва та інтегрованого навчання. Подано опис досвіду проведення тематичних курсів та авторських дистанційний курсів в освітньому середовищі Google Клас. Описано досвід мережевого самонавчання педагогів. Наведено приклади організації онлайн-конкурсів, виставок, мистецьких мандрівок.

\section{ЛIТЕРАТУРА}

1. Закон України «Про освіту». URL: http://osvita.ua/legislation/law/ $2231 / 3$, c. 1

2. Лук'янова Л. Неформальна освіта дорослих як невід'ємна складова освіти впродовж життя. URL: http://www.uaod.org.ua/ data/PRO_OSVITU_DOROSLYH/unformal_OD.PDF.

3. Кондратова Л.Г. Професійний саморозвиток вчителів музичного мистецтва в інформальній освіті. Virtus. Scientific Journal. 2019. Вип. 35. C. $118-122$.

4. Мукан Н.В., Грогодза І.Ю. Професійний розвиток педагогів: теоретичні та методологічні аспекти. Педагогічні науки: теорія, історія, інноваційні технологї̈. 2013. № 5 (31). С. 18-21.

5. Нова українська школа. Концептуальні засади реформування середньої освіти / Міністерство освіти і науки України. 2016. С. 11-12. URL: https://www.kmu.gov.ua/storage/app/media/reforms/ukrainska-shkolacompressed.pdf.

6. Сорочан Т.М., Данильєв А.О., Дьяченко Б.А., Рудіна О.М. Професійний розвиток керівників i педагогічних працівників загальноосвітніх навчальних закладів у післядипломній педагогічній освіті регіонального рівня (за матеріалами Луганського обласного інституту післядипломної педагогічної освіти). Луганськ : СПД Рєзніков В.С., 2013. 524 с.

7. Ingvarson L. Professional development as the pursuit of professional standards: the standard based professional development system. Teaching and Teacher Education. 1998. № 14 (1). P. 127-140.

8. Hrynevych, L., Elkin, O., Kalashnikova, S., Kobernyk, I., Kovtunecj, V., Makarenko, O., Shy jan, R. New Ukrainian School: Conceptual Principles for Reforming the Secondary School. 2016. URL: https://www.kmu.gov.ua/storage/ app/media/reforms/ukrainska-shkola-compressed.pdf.

9. Law of Ukraine on the Education of the Verkhovna Rada № 38-39, art.380. 2017. URL: https://zakon.rada.gov.ua/laws/show/2145-19. 
10. Unesco.Unesco Ict Competency Framework For Teachers. Unesco, Paris. 2018. URL: http://unesdoc.unesco.org/images/0026/002657/265 721e.pdf.

11. Scheerens J. Teachers' professional development. Europe in international comparison. An analysis of teachers' professional development based on the OECD's Teaching and Learning International Survey (TALIS). Luxembourgh : Office for Official Publications of the European Union, 2010. 204 p.

12. URL: http://search.ligazakon.ua/1_doc2.nsf/link1/TF030830.html.

13. URL: http://otr.iod.gov.ua/images/pdf/2017/10/04.pdf.

14. URL: http://www.model.poltava.ua/index.php?option=com content\&view $=$ article $\&$ id $=377$ : metod-integra .

15. URL: https://lib.iitta.gov.ua/5798/1/tmpA469.pdf.

16. URL: https://mon.gov.ua/ua/osvita/visha-osvita/distancijna-osvita.

Information about the authors: Kondratova L. G.,

Ph.D. in Pedagogical Sciences, Associate Professor at the Department of Open Educational Systems and Information and Communication Technologies State Higher Education Institution "University of Management of Education" of the National Academy of Pedagogical Sciences of Ukraine 52-A, Sich Riflemen, Kiev, Ukraine

Ruzhytskyi V. A., Ph.D. in Pedagogical Sciences, Director of Communal Higher Educational Establishment of Kyiv Regional Council "Bila Tserkva Humanities Pedagogical College" 37, Yaroslava Mudrogo str., Bila Tserkva, Kiev region, Ukraine 